\title{
Heterogeneity in recombinant protein production
}

Schalén, Martin; Johanson, Ted; Lundin, Luisa; Sørensen, Søren; Eliasson Lantz, Anna

Published in:

New Biotechnology

Link to article, DOI:

10.1016/j.nbt.2012.08.217

Publication date:

2012

Document Version

Publisher's PDF, also known as Version of record

Link back to DTU Orbit

Citation (APA):

Schalén, M., Johanson, T., Lundin, L., Sørensen, S., \& Eliasson Lantz, A. (2012). Heterogeneity in recombinant protein production. New Biotechnology, 29S, S78. https://doi.org/10.1016/j.nbt.2012.08.217

\section{General rights}

Copyright and moral rights for the publications made accessible in the public portal are retained by the authors and/or other copyright owners and it is a condition of accessing publications that users recognise and abide by the legal requirements associated with these rights.

- Users may download and print one copy of any publication from the public portal for the purpose of private study or research.

- You may not further distribute the material or use it for any profit-making activity or commercial gain

- You may freely distribute the URL identifying the publication in the public portal

If you believe that this document breaches copyright please contact us providing details, and we will remove access to the work immediately and investigate your claim. 


\section{Poster 1.4.13}

\section{Heterogeneity in recombinant protein production}

Martin Schalén ${ }^{1, *}$, Ted Johanson ${ }^{1}$, Luisa Lundin $^{2}$, Søren J. Sørensen ${ }^{2}$, Anna Eliasson Lantz ${ }^{1}$

${ }^{1}$ Center for Microbial Biotechnology, Department of Systems Biology, Technical University of Denmark, Building 223, Søltofts Plads, 2800 Kgs. Lyngby, Denmark

${ }^{2}$ Molecular Microbial Ecology Group, Department of Biology, University of Copenhagen, Sølvgade 83H, DK-1370K Copenhagen, Denmark

A crucial step in biotechnology is the scale-up process. Normally, lab scale verification and optimization of production processes and strains are performed in small reactors with perfect mixing and hence the cells experience a homogenous environment. The gradients that occur in industrial scale bioreactors are often not taken into consideration in these experiments. Gradients occur due to insufficient mixing in the reactor, and affect the process in a variety of ways. When cells travel through the reactor and encounter different substrate concentrations, oxygen availability, $\mathrm{pH}$, temperature, etc. the cell physiology is affected. Cells are stressed, and this may severely affect growth, by-product accumulation, biomass yield and recombinant product yield. The stress caused by exposure to divergent microenvironments, genetic differences of individual cells, differing cell cycle stage and cell age, all contribute to make a population in a fermenter heterogeneous, resulting in cell-to-cell variation in physiological parameters of the microbial culture.

Our study aims at investigating how population heterogeneity and recombinant protein production is affected by environmental gradients in bioreactors. For this purpose, a Saccharomyces cerevisiae strain, that functions as a protein production reporter, has been developed. A heterologous protein has been tagged with a fluorescent protein providing a way to measure the amount of heterologous protein produced by the cells on single cell level. Gradients are simulated in small bioreactors and the population heterogeneity can be visualised by analysing single cells with flow cytometry. This can give new insights to cell physiology and recombinant protein production at the industrial scale.

Keywords: Population heterogeneity; Recombinant protein production; Scale-down

http://dx.doi.org/10.1016/j.nbt.2012.08.217

Poster 1.4.14

Dismistifying the involvement of cell surface hydrophobicity and biosurfactant production in $\mathrm{W} / \mathrm{O}$ demulsification activity of bacteria

Rita de Cássia Rocha Fernandes*, Arnaldo Chaer Borges, Marcos Rogério Tótola

Departamento de Microbiologia, Universidade Federal de Viçosa, ECS, sala 141, Campus da UFV, Centro, Viçosa, MG 36570-000, Brazil

We evaluated the hypothesis that the capability of bacterial isolates to break oil-in-water $(\mathrm{O} / \mathrm{W})$ or water-in-oil $(\mathrm{W} / \mathrm{O})$ emulsions depends on cell surface hydrophobicity $(\mathrm{CSH})$ and the production of biosurfactants. Among 12 bacterial isolates obtained from enrichment of solid waste compost, four were shown to be efficient in breaking $\mathrm{W} / \mathrm{O}$ emulsion (emulsion breaking ratio $>70 \%$ ). These strains were identified as Acinetobacter sp. and Pseudomonas mendocina. None produced biosurfactants or were able to break $\mathrm{O} / \mathrm{W}$ emulsion. We concluded that biosurfactant production is not required for $\mathrm{W} / \mathrm{O}$ emulsion breaking, but may be required for breaking $\mathrm{O} / \mathrm{W}$ emulsions. W/O emulsion-breaking activity (EBA) decreased with culture age. EBA of young cultures (22 hours of growth) was dependent on the presence of cells, and soluble deemulsifier(s) did not have significant effect at this stage. In contrast, EBA of older cultures (198 hours of growth) was attributed to the presence of non-surfactant deemulsifier compound(s) in the culture broth. An antagonistic effect of emulsion stabilization or destabilization by pelleted and floating cells in the same culture of some strains was observed. Experiments with Acinetobacter sp. LBBMA LU3 revealed that cell integrity is not required for EBA. EBA was insensitive to variation of $\mathrm{pH}$ (3-8) or salt concentration $\left(0-150 \mathrm{gl}^{-1} \mathrm{NaCl}\right)$, but increased linearly with temperature $\left(30-60^{\circ} \mathrm{C}\right)$. Correlation between $\mathrm{CSH}$ and EBA was either absent, negative or positive, depending on the microbial strain or on previous growth condition for a particular strain. We conclude that $\mathrm{CSH}$ and biosurfactants are not primary factors determining W/O-EBA of bacterial cells.

Acknowledgments: We want to thanks CNPq for financial support to the project and FAPEMIG for the financial support to attend the ECB15.

http://dx.doi.org/10.1016/j.nbt.2012.08.218

\section{Poster 1.4.15}

Enzyme stability studies in microplates and stirred mini-bioreactors as representative scaling systems in heterogeneous biocatalysis

Maria Ribeiro, Mario Nunes*, Pedro Fernandes

Faculty of Pharmacy, Lisboa, Portugal

For process development, miniaturization allows for significant time, labor, and resources savings, given the high parallelization and automation capabilities, and the low volumes required. Microtiter plates (MTP) and miniature stirred reactors (MSR) have been widely used within this concept. Major developments have been made in these matters when carrier-free cell/enzyme systems are involved, but application to support based systems have been overlooked, efforts focusing in microstructured reactors. The goal of the present work is to contribute to fill in such gap, by establishing MTP and MSR as high throughput platforms for a robust scale down approach of bioconversion systems involving immobilized enzymes with operational stability evaluation. The model system used was the hydrolysis of naringin by naringinase encapsulated in polyvinyl alcohol lens shaped particles, which display high chemical and mechanical stability. The initial approach to the process scale design relied on bioconversion trials at different scales with MTP and in-house specifically built MSR. The effect of the ratio of biocatalyst particle size to reactor size and stirrer was also assessed. Axial flow favored naringin hydrolysis, whereas in MTP the geometry of the well hardly influenced the bioconversion. This work provides an innovative approach, for up to date MTP and MSR 